\title{
Inhibition of apoptosis may lead to the development of bortezomib resistance in multiple myeloma cancer cells
}

\section{[Apoptozisin inhibisyonu, multiple myeloma kanser hücrelerinde bortezomib direnci gelişmesine yol açabilir]}

https://doi.org/10.1515/tjb-2019-0521

Received December 22, 2019; accepted March 30, 2020; published online July 27,2020

\begin{abstract}
Background: Multiple myeloma (MM), a malignancy of plasma cells, is the second most prevalent hematological cancer. Bortezomib is the most effective chemotherapeutic drug used in treatment. However, drug-resistance prevents success of chemotherapy. One of the factors causing drugresistance is dysfunction of apoptotic-pathways. This study aimed to evaluate the relationship between expression levels of Bcl-2, Bax, caspase-3 and p-53 genes involved in apoptosis and the development of bortezomibresistance in MM cell lines.

Materials and methods: Multiple myeloma KMS20 (bortezomib-resistant) and KMS28 (bortezomib-sensitive) cell lines were used. 3-[4,5-Dimethylthiazol-2-yl] 1-2,5-diphenyltetrazolium bromide (MTT) assay was performed to determine $\mathrm{IC}_{50}$ values of bortezomib. RNAs were isolated from bortezomib-treated cell lines, followed by cDNA synthesis. Expression levels of the genes were analyzed by using q-Realtime-PCR.
\end{abstract}

*Corresponding author: Emine Öksüzoğlu, Molecular Biology Division, Department of Biology, Faculty of Science and Letters, Aksaray University, Aksaray, 68100, Turkey. Tel: +90 5325793125 , E-mail: emineoksuzoglu@hotmail.com. https://orcid.org/00000003-4106-1056

Gül Kozalak: Molecular Biology Division, Department of Biology, Faculty of Science and Letters, Aksaray University, Aksaray 68100, Turkey, E-mail: gulkozalak@gmail.com. https://orcid.org/00000002-2928-6474
Results: As a result, Bcl-2/Bax ratio was higher in KMS20 (resistant) cells than in KMS28 (sensitive) cells. Expression of caspase-3 decreased in KMS20-cells, whereas increased in KMS28-cells. The results indicate that apoptosis was suppressed in resistant cells.

Conclusion: These findings will enable us to understand the molecular mechanisms leading to drug-resistance in MM cells and to develop new methods to prevent the resistance. Consequently, preventing the development of bortezomib resistance by eliminating the factors which suppress apoptosis may be a new hope for MM treatment.

Keywords: Multiple Myeloma; Bortezomib; Drug-Resistance; Apoptosis; BcI-2/Bax; Cancer.

Öz

Amaç: Plazma hücrelerinin malignitesi olan multiple myeloma (MM), en yaygın ikinci hematolojik kanserdir. Bortezomib, MM tedavisinde kullanılan en etkili kemoterapötik ilaçlardan birisidir. Bununla birlikte, ilaca karşı oluşan direnç kemoterapinin başarısını önler. İlaç direncine neden olan faktörlerden biri apoptotik yolakların fonksiyon bozukluğudur. Bu çalışmada, apoptoziste rol alan Bcl-2, Bax, kaspaz-3 ve p-53 genlerinin ekspresyon düzeyleri ile MM hücre hatlarında bortezomib direnci gelişimi arasındaki ilişkiyi değerlendirmeyi amaçladık.

Gereç ve yöntem: Multiple myeloma KMS20 (bortezomibdirençli) ve KMS28 (bortezomib-hassas) hücre hatları kullanıldı. Bortezomib'in IC $_{50}$ değerlerini belirlemek için MTT testi uygulandı. Bortezomib ile muamele edilmiş hücre hatlarından RNA'lar izole edildi, ardından cDNA sentezi 
yapıldı. Genlerin ekspresyon düzeyleri, q-Realtime-PCR kullanılarak analiz edildi.

Bulgular: Sonuç olarak, Bcl-2 / Bax oranı KMS20 (dirençli) hücrelerinde, KMS28 (hassas) hücrelerine göre daha yüksek bulundu. Kaspaz-3 ekspresyonu, KMS20 hücrelerinde azalırken, KMS28 hücrelerinde artmıştır. Sonuçlar, dirençli hücrelerde apoptozisin baskılandığını göstermektedir.

Sonuç: $\mathrm{Bu}$ bulgular, $\mathrm{MM}$ hücrelerinde ilaç direnci gelişimine yol açan moleküler mekanizmaları anlamamızı ve direnci önlemek için yeni yöntemler geliştirmemizi olanak sağlayacaktır. Sonuç olarak, apoptozisi baskılayan faktörleri ortadan kaldırarak bortezomib dirençliliğinin gelişmesini önlemek, MM tedavisi için yeni bir umut olabilir.

Anahtar kelimeler: Multiple Myeloma; Bortezomib; İlaç-Dirençliliği; Apoptozis; BcI-2/Bax; Kanser.

\section{Introduction}

Multiple myeloma (MM), the second most common type of hematologic cancer in the world, is characterized by the accumulation of monoclonal $\mathrm{B}$ cell-derived malignant plasma cells in the bone marrow [1-3]. The prevalent clinic symptoms of the disease are lytic bone lesions, anemia, hypercalcemia, osteoporosis and renal failure [4]. The accumulation of malignant cells in the bone marrow disrupts the balance of blood cells and immune system in patients [5]. Generally, the median survival time of MM patients is 2.5-3 years [3], while this can be increased to 45 years by new chemotherapeutic drugs $[5,6]$. In the last decade, advances have been made in the treatment of MM, such as the discovery of new agents and inhibitors targeting the proteasome.

The proteasome complex is responsible for the degradation of regulatory proteins involved in pathways such as cell cycle, apoptosis and DNA repair, which are of crucial importance for the survival of the cell [7]. In this system, disruption of proteasome functions leads to see above growth arrest, induction of apoptosis, and as a result cell death [8]. The proteasome is an excellent therapeutic target in oncology, since tumor cells generally have a higher proteasome activity than normal cells $[9,10]$.

Bortezomib (PS-341, Velcade) is the first class proteasome inhibitor approved by the United States Food and Drug Administration for the treatment of MM in 2003 [11-13]. Since then, it has become an indispensable drug leading to improvements in the treatment for MM patients. Bortezomib inhibits the proteasome and suppresses tumor growth, spread and angiogenesis, reducing the chance of tumor survival [12]. It also inhibits the activation of NF-kb and causes apoptosis in the tumor cell [13]. While bortezomib is among the drugs with the best outcomes in clinical treatment of MM, drug resistance is frequently observed in MM patients [14]. At the beginning of the clinical treatment of MM most patients are cured with bortezomib, but after a while they acquire resistance. Therefore, it is important to understand and prevent the mechanisms that cause drug resistance in the treatment of MM. In tumor cells, overexpression of drug transport proteins, inhibition of apoptosis, and degradation of cell cycle signaling pathways are crucial mechanisms leading resistance to chemotherapeutic drugs [15].

Although each chemotherapeutic drug has its own specific target, in the end the majority of them commonly trigger apoptosis. Therefore, a dysfunction in the pathway of apoptosis contributes to the development of drug resistance [16]. MM cells lose their apoptotic controls and accumulate in the bone marrow where various cytokines can survive by autocrine or paracrine activation. This suggests that apoptosis inhibition is a serious problem in both resistance and pathogenesis in the treatment of MM [17].

Apoptosis, defined as programmed cell death, triggers either extrinsic pathway with the death receptor or intrinsic pathway with the mitochondria, and at the end of both pathways activation of the caspases occurs [18]. Chemotherapeutic agents generally act by the intrinsic pathway, and this pathway is regulated by the Bcl-2 family members, which contain both pro-apoptotic and anti-apoptotic proteins.

The anti-apoptotic proteins of the Bcl-2 family that prevent apoptosis are $\mathrm{Bcl}-2, \mathrm{Bcl}-\mathrm{xL}$, whereas the proapoptotic proteins that induce apoptosis are Bax and Bak [19]. It was found that the imbalances in expressions of Bcl2 family members resulted in drug resistance, malignancy and tumor aggression associated with apoptosis [17]. It has been investigated in many studies that increased expression levels of Bcl-2 and Bcl-xL that are associated with MM cell survival and resistance to various chemotherapeutic drugs [20-22]. Furthermore, some studies have also reported that overexpression of anti-apoptotic members are associated with resistance to chemotherapeutic drugs $[15,17]$.

$\mathrm{P}-53$, known as the guardian of the genome, is another important gene involved in the mechanism of apoptosis. P-53 enables the regulation of genes in important mechanisms such as DNA repair, cell cycle arrest and apoptosis as expected from a tumor suppressor protein. Astonishingly, p-53 itself is capable of triggering both apoptosis or cell survival. P-53 gene mutation, translocation and deletion 
studies have shown that these cause drug resistance, and therefore it is very important in cancer treatment $[23,24]$.

Caspases are mediating molecules in the apoptosis pathway and caspase- 3 is the maximum activated protein amongst them. This is because, it is a death protease that catalyzes the cleavage of most important key proteins in apoptosis mechanism. Some studies have reported that the loss of caspase-3 expression contributes to the development of drug resistance [16].

Initially, most MM patients respond well to bortezomib, but patients develop bortezomib resistance at later stages. This drug-resistance is one of the imperative problems to be solved in multiple myeloma patients facing a continuing struggle due to the persistence of drugresistant tumor cells [14]. In conclusion, in order to get over the bortezomib resistance in MM, it is essential to analyze and prevent the mechanisms that cause this resistance [25].

Therefore, we aimed to investigate the role of the apoptosis mechanism at developing bortezomib resistance in multiple myeloma cells. In this study, expression levels of Bcl-2, Bax, caspase-3 and p-53 genes in apoptosis pathway which are thought to be related to bortezomib resistance in MM cells were investigated.

\section{Materials and methods}

\section{Chemicals and reagents}

Bortezomib (Velcade, PS-341) was provided by Millennium Pharmaceuticals (Cambridge, MA). MTT (3-[4,5-Dimethylthiazol-2-yl] 12,5-diphenyltetrazolium bromide), Dulbecco's Phosphate-BufferedSaline (DPBS), Roswell Park Memorial Institute (RPMI) 1640, FetalBovine Serum (FBS) and Penicillin-Streptomycin were purchased from Life Technologies, DMSO (Dimethylsulfoxide) was obtained from Santa Cruz.

\section{Cell culture}

Human multiple myeloma cell lines, KMS-20 (bortezomib-resistant) and KMS-28 (bortezomib-sensitive) were originally obtained from the JCRB-Japanese Collection of Research Bioresources Cell Bank. The multiple myeloma cell lines were routinely cultured in RPMI 1640 medium which was supplemented with $10 \%$ (v/v) FBS, 2 mM Lglutamine and $1 \%$ penicillin-streptomycin solution. The cells were grown in $75 \mathrm{~cm}^{2}$ flasks in an incubator at $37^{\circ} \mathrm{C}$ in a humidified atmosphere containing $5 \% \mathrm{CO}_{2}$ and freshly subcultured before each experiment to be in the exponential phase of growth.

\section{The MTT cell proliferation assay}

We used the MTT assay to determine cell viability and cytotoxicity of bortezomib. In brief, the cells were seeded in 96-well microtiter plates

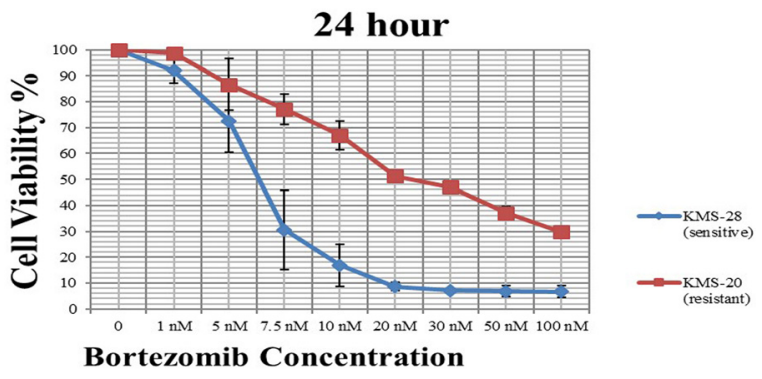

Figure 1: Effect of bortezomib on cell viability in KMS-20 (red) and KMS-28 (blue) cell lines at $24 \mathrm{~h}$. $\mathrm{IC}_{50}$ values represent means of three independent experiments \pm SD.

with $1 \times 10^{6}$ cell/well in $100 \mu \mathrm{l}$ of RPMI 1640 medium supplemented with $10 \% \mathrm{FBS}$ and cultured in a humidified incubator (at $37{ }^{\circ} \mathrm{C}$ in $5 \%$ $\mathrm{CO}_{2}$ ) for $24 \mathrm{~h}$. Then, the cell lines were exposed to different doses (from 1 to $100 \mathrm{nM}$ ) of bortezomib separately and were incubated for a further $24 \mathrm{~h}$. After treatment, $20 \mu \mathrm{l}$ MTT solution was added to each well and incubated for a further $4 \mathrm{~h}$. The medium was aspirated and $100 \mu \mathrm{l}$ DMSO was added to dissolve the formazan crystals. The dark blue formazan crystals formed with in the viable cells were solubilized with DMSO and the absorbance (OD) of each well was measured with the ChroMate ELISA plate reader. The percentage viability of the cell in each well compared with the control was calculated on Microsoft Excel and created graphics (Figure 1). The inhibitor concentration $\left(\mathrm{IC}_{50}\right)$ of bortezomib was calculated by non-linear regression analysis using GraphPad Prism 7 program (Table 2). Three independent experiments were performed to determine the $\mathrm{IC}_{50}$ values of bortezomib in the both cell lines and averaged.

\section{RNA isolation and CDNA synthesis}

For RNA isolation, multiple myeloma KMS-20 and KMS-28 cell lines were grown within $24 \mathrm{~h}$, and then cultured with certain concentrations of bortezomib for $24 \mathrm{~h}$. RNA isolation from the cells was performed using Thermo-Fisher Scientific Pure Link-RNA Mini Kit (Life Technologies, Carlsbad, CA) according to its protocol. Concentrations of RNAs isolated were measured by NanoDrop 2000 spectrophotometer (Thermo-Scientific, Waltham, MA). The RNAs were run in $1 \%$ agarose gel electrophoresis for purity control.

cDNA synthesis from total RNA was performed according to the High-Capacity cDNA Reverse Transcription Kit (Thermo-Fisher Scientific, Waltham, MA) protocol. Synthesized cDNAs were diluted with RNAse-free $\mathrm{H}_{2} \mathrm{O}$ for $1 \mathrm{~h}$ and stored frozen at $-20^{\circ} \mathrm{C}$ till gene expression determination.

\section{Gene expression analysis by quantitative real-time PCR}

Gene expression analysis (RT-qPCR) was performed using a multiplex polymerase chain reaction (PCR) method on 7500 Fast Real Time PCR (Applied Biosystems, Foster City, CA). The superiority of this method over monoplex PCR is that more than one gene can be run in a single well, so that the expression of more than one gene can be merged in one experiment. Process steps were performed according to theTaqMan Gene Expression Master Mix protocol (Thermo Fisher Scientific, Waltham, MA) by using gene-specific primer probes (Table 1). 
Table 1: Taqman gene expression assay IDs for the genes.

\begin{tabular}{ll}
\hline Gene & ID \\
\hline Bcl-2 & Hs00608023_m1 (FAM) \\
Bax & Hs00180269_m1 (FAM) \\
Caspase-3 & Hs00234387_m1 (FAM) \\
P-53 & Hs01034249_m1 (FAM) \\
$\beta$-Actin & (VIC-MGB) (internal control) \\
\hline
\end{tabular}

The quantity of gene expression was evaluated using TaqMan Gene Expression Assays on 7500 Real Time PCR System. $\beta$-Actin was used as an internal control, and reaction mixture without cDNA as negative control. Amplification steps were performed in 40 cycles of $20 \mathrm{~s}$ at $50{ }^{\circ} \mathrm{C} ; 10 \mathrm{~min}$ at $95^{\circ} \mathrm{C} ; 15 \mathrm{~s}$ at $95^{\circ} \mathrm{C}$ and $1 \mathrm{~min}$ at $60^{\circ} \mathrm{C}$. Three independent experiments were averaged for each cDNA.

The raw data was analyzed with SDS 1.4 software program (Thermo Fisher Scientific, Waltham, MA) and relative fold change of expression for each gene was calculated using $\Delta \Delta \mathrm{Ct}$ approach. The relativity between groups was calculated according to the following Eq. (1).

$$
\mathrm{RQ}(\text { Relative Quantitation })=2^{-\Delta \Delta \mathrm{ct}}
$$

\section{Statistical analysis}

The significance of the change in expression of studying genes was identified by ANOVA test $(p<0.05)$. Statistical differences between groups was determined by Dunnett test $(p<0.05)$. GraphPad Prism 7 program (GraphPad Software, San Diego, CA) is used for all calculations.

\section{Results}

\section{Cytotoxic effect of bortezomib on the cell lines}

According to the MTT assay, the cell viability curve versus bortezomib doses in KMS-20 and KMS-28 cell lines was shown in Figure 1. The proliferation inhibitory effect of bortezomib on the cells is expressed as $\mathrm{IC}_{50}$, which is the compound concentration required to inhibit cell growth by $50 \%$. In this study, the $\mathrm{IC}_{50}$ values of bortezomib for each cell line were determined. According to our results, the $\mathrm{IC}_{50}$ value of KMS-20 cell line against bortezomib doses within $24 \mathrm{~h}$ was $25.64 \mathrm{nM}$, whereas the $\mathrm{IC}_{50}$ value of KMS-28 cell

Table 2: $I_{50}$ values of bortezomib in the $M M$ cell lines.

\begin{tabular}{lllr}
\hline Cell line & Time & IC $_{\mathbf{5 0}}$ & Standard error \\
\hline KMS-20 (resistant) & $24 \mathrm{~h}$. & $25.64 \mathrm{nM}$ & \pm 1.08 \\
KMS-28 (sensitive) & $24 \mathrm{~h}$. & $6.29 \mathrm{nM}$ & \pm 1.06 \\
\hline
\end{tabular}

Table 3: Real time-PCR results of the genes depending on the increase at bortezomib doses *

\begin{tabular}{|c|c|c|c|c|c|c|}
\hline \multirow[b]{2}{*}{ Gene } & \multicolumn{3}{|c|}{ KMS-20 cell line $24 \mathrm{~h}$. } & \multicolumn{3}{|c|}{ KMS-28 cell line $24 \mathrm{~h}$. } \\
\hline & Control & $5 n M$ & $25 n M$ & Control & $5 n M$ & $25 n M$ \\
\hline $\mathrm{Bcl}-2$ & 1 & 1.07 & 2.77 & 1 & 1.68 & 0.39 \\
\hline Bax & 1 & 0.94 & 2.46 & 1 & 3.43 & 4.44 \\
\hline Caspase-3 & 1 & 0.18 & 1.63 & 1 & 2.45 & 1.63 \\
\hline P-53 & 1 & 1.15 & 2.82 & 1 & 1.58 & 0.40 \\
\hline
\end{tabular}

* Quantities (relative fold-change) of the gene expressions were calculated using $\Delta \Delta \mathrm{Ct}$ approach.

line was 6.29 nM (Table 2). Resistance Indices (RIs) of the multiple myeloma cell lines were determined according to the following formula (2).

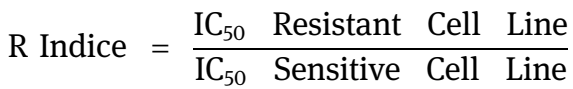

As a result, it was found that KMS-20 cells showed a 4-fold resistance against bortezomib compared with KMS28 cells at $24 \mathrm{~h}$. The results of our study indicated that the KMS-20 cell line was resistant to bortezomib, while the KMS-28 cell line was sensitive.

\section{Real time-qPCR gene expression analysis results}

The expression levels of Bcl-2, Bax, caspase-3 and p-53 genes were analyzed by Realtime-qPCR at different doses of bortezomib in KMS-20 and KMS-28 cell lines. The relative mRNA expressions of the target genes were determined by using the $2^{-\Delta \Delta c t}$ method.

In KMS-20 cells, we found that Bcl-2 expression ( 2.77-fold) increased more than Bax expression ( 2.46-fold) at $25 \mathrm{nM}$ bortezomib dose in $24 \mathrm{~h}$. Also, the expression of $\mathrm{p}-53$ gene ( $\sim 2.82$-fold) has increased. However, it was determined that caspase-3 ( 0.18-fold) expression decreased at $5 \mathrm{nM}$ bortezomib dose (Table 3, Figure 2A).

In KMS-28 cells, it was found that the expression of Bax gene increased $\sim 3.43$-fold at $5 \mathrm{nM}$ bortezomib dose and $\sim$ 4.44-fold at $25 \mathrm{nM}$ bortezomib dose. Whereas, the Bcl-2 gene expression decreased $\sim 0.39$-fold at $25 \mathrm{nM}$ bortezomib dose. At the same time, caspase- 3 gene expression showed $\mathrm{a} \sim 2.45$-fold increase at $5 \mathrm{nM}$ bortezomib dose (Table 3, Figure 2B).

As a result, the $\frac{B c l-2}{B a x}$ ratio was 1.14 at $5 \mathrm{nM}$ bortezomib dose in the KMS-20 (resistant) cell line, whereas it was 0.49 in the KMS-28 (sensitive) cell line. For $25 \mathrm{nM}$ bortezomib dose, the $\frac{B C l-2}{B a x}$ ratio was found to be 1.13 in the KMS-20 cell line and 0.09 in the KMS-28 cell line (Table 4). 

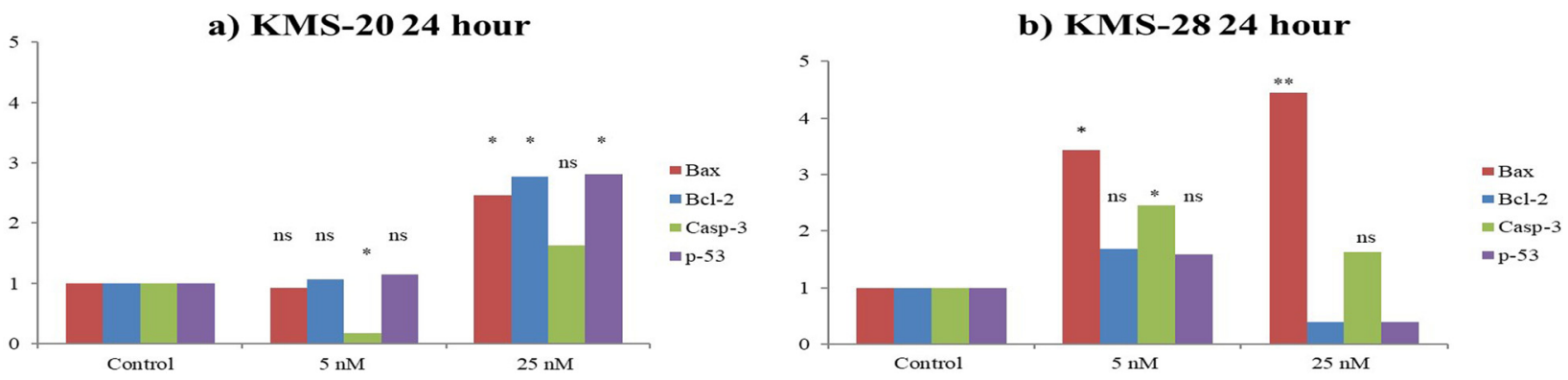

Figure 2: Expression levels of apoptosis related genes depending on increase at bortezomib doses A) in KMS-20 cell line B) in KMS-28 cell line within $24 \mathrm{~h}$. Each gene is pointed same color in all graphs. The expression level of Bax is pointed in red, $\mathrm{Bcl}-2$ is pointed in blue, caspase-3 is

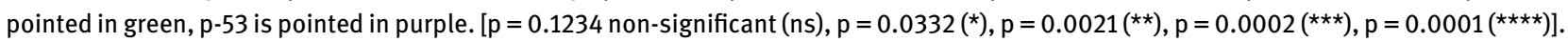

Table 4: The Bcl-2/Bax ratios in the MM cell lines versus the bortezomib doses.

\begin{tabular}{lllllr}
\hline & \multicolumn{2}{c}{ KMS-20 (resistant) } & & \multicolumn{2}{c}{ KMS-28 (sensitive) } \\
\cline { 2 - 3 } \cline { 6 - 6 } & $\mathbf{5 n M}$ & $\mathbf{2 5 n M}$ & & $5 \mathrm{nM}$ & $\mathbf{2 5 ~ n M}$ \\
\hline$\frac{B C L-2}{B A X}$ & 1.14 & 1.13 & & 0.49 & 0.09 \\
\hline
\end{tabular}

\section{Discussion}

MM is a malignant plasma cell disorder characterized by the accumulation of tumor cells in the bone marrow [26]. Although there are many clinically recommended treatment regimens for the treatment of MM, bortezomib is the most effective drug among them. However, it has been observed that MM patients developed resistance to bortezomib during the course of treatment. Although studies so far have focused on drug resistance during MM treatment, we still do not know how MM cells survive in the presence of such effective treatments [15]. The 10-year survival rate of 3\% shows how difficult it is to treat MM [3]. Therefore, in order to get over the bortezomib resistance in $\mathrm{MM}$, it is essential to analyze the mechanisms that cause this problem [25]. Although the mechanism of drug resistance in MM has not been fully elucidated, it is clear that apoptotic pathway is associated with this resistance. Disorders of the apoptosis function have been shown to mediate selection of drug-resistant cell colonies [16, 27].

Based on this understanding, we investigated the relationship between the expression of Bcl-2, Bax, p-53 and caspase- 3 genes involved in regulation of apoptosis and the development of bortezomib resistance in MM cell lines.

Apoptosis is governed by a complex network of interactions between anti-apoptotic and pro-apoptotic proteins of Bcl-2 family. The balance between these family members help preserve organism health by regulating cell death during development [28]. The disproportionate expression of pro-apoptotic (Bax) and anti-apoptotic (Bcl-2) genes results in disruption of the apoptotic pathway, thus, drug resistance, malignancy and aggressiveness of various tumors [17]. Various studies on drug resistance in cancer cells have shown that apoptosis suppressor (anti-apoptotic) proteins are very important in the development of resistance. Tumor cells suppress apoptosis by increasing the production of anti-apoptotic proteins against chemotherapeutic drugs and eventually the cancer cells survive by developing resistance [17, 29]. Inhibition of apoptosis can asist cancer cells survival in many ways, such as increasing tumor cell growth, facilitating metastasis spread, and providing drug resistance. Therefore, it is not surprising that overexpression of Bcl-2 family members, which enables the survival of cells, is found in many types of cancer. This upregulation can take place through a variety of mechanisms, including chromosomal translocation, gene amplification, increased gene expression, and increased protein stability $[29,30]$. Some studies have suggested that anti-apoptotic genes overexpression may contribute to the development of drug resistance in MM cells exposed to chemotherapeutic drugs [15, 17].

In cells in which apoptosis is suppressed, the expression of the Bcl-2 gene increases, while the expression of the Bax gene decreases. So, the $\frac{B c l-2}{B a x}$ ratio is indicative of whether apoptosis is induced or not. The increase of this ratio causes the suppression of apoptosis because Bcl-2 expression is increased more than Bax. In contrast, the decrease in the ratio is due to increased Bax expression and consequently apoptosis is induced [17, 29, 31].

According to the results of our study, at $5 \mathrm{nM}$ bortezomib dose, the $\frac{B C l-2}{B a x}$ ratio was found to be 1.14 in multiple myeloma KMS-20 (resistant) cell line and 0.49 in KMS-28 (sensitive) cell line. At a dose of $25 \mathrm{nM}$ bortezomib, the $\frac{B c l-2}{B a x}$ ratio was 1.13 in the resistant cell line, while 0.09 in the 
sensitive cell line (Tables 3 and 4). We found that the $\frac{B c l-2}{B a x}$ ratio increases in favour of the Bcl-2 gene in KMS-20 (resistant) cell line. Thus, apoptosis is suppressed in this cell line. On the other hand, since the ratio in KMS-28 (sensitive) cell line is in favour of the Bax gene, therefore, apoptosis is induced in this cell line (Table 3; Figure 2A,B). These findings showed us that apoptosis was suppressed in KMS-20 cells and consequently resistance to bortezomib was developed. In contrast, KMS-28 cells have become sensitive to bortezomib by induction of apoptosis.

The common component of the mechanism of apoptosis is a proteolytic system consisting of a family called caspase. As is known, caspase- 3 is the most widely studied protease and is the main protein that causes apoptosis. It has been reported in some studies, that apoptosis is suppressed by the decline of Bax expression or loss of caspase-3 in various types of cancer [16]. Our results indicated that the expression of caspase- 3 gene decreased in KMS-20 (resistant) cell line at $5 \mathrm{nM}$ bortezomib dose, while increased $\sim 2.45$-fold in KMS-28 (sensitive) cell line (Table 3; Figure 2A,B). This is further evidence that apoptosis is suppressed in bortezomib-resistant cells, while induced in bortezomib-sensitive cells.

Functions of the p-53 gene, known as the guardian of the genome, include DNA repair, cell cycle arrest, and regulation of pathways associated with apoptosis [32]. If the damage is repairable, it stops the cell cycle in the G1 phase when DNA damage occurs and allows time for the cell to repair its DNA. If DNA damage is too great to be repaired, then p-53 induces apoptosis. Mutations in the p53 gene are modifications in the pro-apoptotic balance causing drug resistance. Overexpression of mutated $p-53$ is often connected to resistance to drugs [32]. According to the results of our study, in KMS-20 (resistant) cell line was observed to have an increase of $\mathrm{p}-53$ gene expression (Table 3; Figure 2A). This may indicate that the cells were standing in G1 phase and attempting to repair the damage. In this way, DNA repair in the KMS-20 cells is taking place despite high doses ( $25 \mathrm{nM}$ ) of the bortezomib and eventually the cells become resistant to bortezomib and continue to live.

The results of our study indicate that apoptosis inhibition is one of the causes of bortezomib resistance in multiple myeloma cells. The results of this study will enable us to understand the molecular mechanisms leading to drug resistance in MM cells and to develop new methods to prevent the resistance. In conclusion, preventing the development of bortezomib resistance by eliminating the factors which suppress apoptosis may create a new hope for MM treatment.
Acknowledgements: The manuscript has previously been orally presented in TBS International Biochemistry Congress 2018/29th National Biochemistry Congress, 26-30 October 2018, Bodrum/Muğla.This study was supported by Aksaray University Scientific Research Project under Grant number 2017-016.

Author contribution: All the authors have accepted responsibility for the entire content of this submitted manuscript and approved submission.

Competing interest: The authors declare that there is no conflict of interests regarding the publication of this article.

\section{References}

1. Yu W, Chen Y, Xiang R, Xu W, Wang Y, Tong J, et al. Novel phosphatidylinositol 3-kinase inhibitor BKM120 enhances the sensitivity of multiple myeloma to bortezomib and overcomes resistance. Leukemia \& Lymphoma 2017;58:428-37.

2. Hideshima T, Mitsiades C, Tonon G, Richardson PG, Anderson KC. Understanding multiple myeloma pathogenesis in the bone marrow to identify new therapeutic targets. Nature Reviews Cancer 2007;7:585-98.

3. Nass J, Efferth T. Drug targets and resistance mechanisms in multiple myeloma. Cancer Drug Resistance 2018;1:87-117.

4. Lemancewicz D, Bolkun L, Jablonska E, Kulczynska A, BolkunSkornicka U, Kloczko J, et al. Evaluation of TNF superfamily molecules in multiple myeloma patients: correlation with biological and clinical features. Leukemia Research 2013;37: 1089-93.

5. Krishnan SR, Jaiswal R, Brown RD, Luk F, Bebawy M. Multiple myeloma and persistence of drug resistance in the age of novel drugs (Review). International Journal of Oncology 2016;49: 33-50.

6. lida S. Mechanisms of action and resistance for multiple myeloma novel drug treatments. International Journal of Hematology 2016;104:271-2.

7. Adams J. The proteasome: structure, function, and role in the cell. Cancer Treatment Reviews 2003;29:3-9.

8. Obeng EA, Carlson LM, Gutman DM, Harrington WJ Jr., Lee KP, Boise LH. Proteasome inhibitors induce a terminal unfolded protein response in multiple myeloma cells. Blood 2006;107: 4907-16.

9. Dou QP, Li B. Proteasome inhibitors as potential novel anticancer agents. Drug Resistance Updates 1999;2:215-23.

10. Adams J. The proteasome: a suitable antineoplastic target. Nature Reviews Cancer 2004;4:349-60.

11. Blade J, Teresa-Ciberia M, Rosinol L. Bortezomib: A valuable new antineoplastic strategy in multiple myeloma. Acta Oncologica 2005;44:440-8.

12. Boccadora M, Morgan G, Cavenagh J. Preclinical evaluation of the proteasome inhibitor in cancer therapy. Cancer Cell International 2005;5:18.

13. Moreau P, Richardson PG, Cavo M, Orlowski RZ, San-Miguel JF, Palumbo A, et al. Proteasome inhibitors in multiple myeloma: 10 years later. Blood 2012;120(5):947-59. 
14. Song IS, Kim HK, Lee SR, Jeong SH, Kim N, Ko KS, et al. Mitochondrial modulation decreases the bortezomib-resistance in multiple myeloma cells. International Journal of Cancer 2013; 133:1357-67.

15. Abdi J, Chen G, Chang H. Drug resistance in multiple myeloma: latest findings and new concepts on molecular mechanisms. Oncotarget 2013;4:2186-207.

16. Friedrich K, Wieder T, Von-Haefen C, Radetzki S, JaÈnicke R, Schulze-Osthoff $\mathrm{K}$, et al. Overexpression of caspase-3 restores sensitivity for drug-induced apoptosis in breast cancer cell lines with acquired drug resistance. Oncogene 2001;20:274960.

17. Oancea M, Mani A, Hussein MA, Almasan A. Apoptosis of Multiple Myeloma. International Journal of Hematology 2004;80:224-31.

18. Danial NN, Korsmeyer SJ. Cell death: critical control points. Cell 2004;116:205-19.

19. Cory S, Adams JM. The Bcl2 family: regulators of the cellular lifeor-death switch. Nature Reviews Cancer 2002;2:647-56.

20. Chen Q, Ray S, Hussein MA, Srkalovic G, Almasan A. Role of Apo2L/TRAIL and Bcl-2-family proteins in apoptosis of multiple myeloma. Leukemia \& Lymphoma 2003;44:1209-14.

21. Zhang B, Gojo I, Fenton RG. Myeloid cell factor-1 is a critical survival factor for multiple myeloma. Blood 2002;99: 1885-93.

22. Tu Y, Renner S, Xu F, Fleishman A, Taylor J, Weisz J, et al. BCL-X expression in multiple myeloma: possible indicator of chemoresistance. Cancer Research 1998;58:256-62.
23. Bargonetti J, Manfredi JJ. Multiple roles of the tumor suppressor p53. Current Opinion in Oncology 2002;14:86-91.

24. Wang Z, Sun Y. Targeting p53 for Novel Anticancer Therapy. Translational Oncology 2010;3:1-12.

25. Wu YX, Yang JH, Saitsu H. Bortezomib-resistance is associated with increased levels of proteasome subunits and apoptosisavoidance. Oncotarget 2016;7:77622-34.

26. Maes A, Menu E, De Veirman K, Maes K, Vanderkerken K, De Bruyne $E$. The therapeutic potential of cell cycle targeting in multiple myeloma. Oncotarget 2017;8:90501-20.

27. Lü S, Wang J. The resistance mechanisms of proteasome inhibitor bortezomib. Biomarker Research 2013;1(1):13.

28. Campbell KJ, Tait SWG. Targeting BCL-2 regulated apoptosis in cancer. Open Biology 2018;8:180002.

29. Wang CY, Mayo MW, Baldwin AS. TNF- and cancer therapyinduced apoptosis: potentiation by inhibition of NF-kappa B. Science 1996;274:784-7.

30. Cevik O, Turut FA, Acidereli H, Yildirim S. Cyclosporine-A induces apoptosis in human prostate cancer cells PC 3 and DU145 via downregulation of COX-2 and upregulation of TGF $\beta$. Turkish Journal of Biochemistry 2018;44:47-54.

31. Guney Eskiler G, Kani I. In vitro apoptotic effect of Zinc(II) complex with $\mathrm{N}$-donor heterocyclic ligand on breast cancer cells. Turkish Journal of Biochemistry 2019;44:761-8.

32. Hientz K, Mohr A, Bhakta-Guha D, Efferth T. The role of $\mathrm{p} 53$ in cancer drug resistance and targeted chemotherapy. Oncotarget 2017;8:8921-46. 